\title{
$\mathrm{TiAl}$ 소재의 브레이징접합에 대한 최신 기술동향
}

\author{
유 호 천,† \\ *한국과학기술정보연구원 ReSEAT 프로그램 전문연구위원
}

\section{Recent Study of TiAl Brazing}

\author{
Ho-Cheon Yoo, $\dagger$ \\ *KISTI(Korea Institute of Science and Technology Information) ReSEAT Program
}

†Corresponding author : yooho278@reseat.re.kr

\section{1. 서 론}

$\mathrm{TiAl}$ (티타늄 알루미나이트) 합금은 높은 비강도, 내 산화 특성, 뛰어난 크리프강도, 고온에서 높은 강성을 나타내고 있으며, 감마(y)-TiAl로 분류되는 금속간 화 합물이다. TiAl은 가벼운 질량과 열저항성으로 인해 가 장 실용적인 재료로 주목을 받고 있다. 값비싼 니켈 등 을 대체할 수 있는 내열강과 초내열합금(superalloy) 에 대한 대체재료로 매우 전망이 밝으며, 약 $40 \%$ 정도 의 획기적인 무게감량을 기할 수 있으므로 특히 자동차 산업과 항공우주산업에의 적용에 상당히 활성화 될 것 으로 예상하고 있다. 그러나 $\mathrm{TiAl}$ 은 접합부에 취성을 형성하기 쉬워, 접합을 매우 어렵게 하고 있으나 브레 이징 접합은 이러한 문제점을 피할 수 있는 가장 효과 적인 기술로 인정받고 있다. TiAl소재의 접합에 대한 어려움을 해결하면 더욱 그 활용가치가 높을 것으로 예 상되고 있다 ${ }^{1,2)}$.

$\mathrm{TiAl}$ 소재의 브레이징접합에 대한 최신 기술동향을 분석하기 위해서는 NDSL, ScienceDirect, KIPRIS 등의 검색을 하였으며, 해외 및 국내의 $\mathrm{TiAl}$ 브레이징 접합관련 학술지와 특허자료를 입수하여 최근의 연구개 발현황을 분석하였다.

$\mathrm{TiAl}$ 의 브레이징성 향상을 위한 제조조건을 파악하기 위하여 우선 여러 가지 제조조건을 파악하였으며, 기본 적으로 $\mathrm{Ag}$ 계, $\mathrm{Ti}$ 계 용가재(filler metal)의 제조조건을 분석하였으며, TiAl 소재의 브레이징 접합시 제조비용 절감을 위한 경제적 제조방법, 품질향상, 브레이징 온 도의 감소기술 및 취성균열방지 기술을 분석하여 5 10 년 후의 $\mathrm{TiAl}$ 소재의 브레이징 접합기술 및 확대될 수 있는 응용분야를 예측하고 향후 기술을 전망하고 방 향을 제시하여 국내 $\mathrm{TiAl}$ 소재의 브레이징 접합기술의
향상과 경량 내열부품의 개발에 이바지할 수 있도록 하 였다.

\section{TiAl의 브레이징성 향상을 위한 제조조건}

\subsection{TiAl 소재의 접합 특성}

$\mathrm{Ti}-\mathrm{Al}$ 소재의 접합에 GTAW, 브레이징, 레이저 용 접, 전자빔용접과 같은 종래의 용융용접방법이 종종 사 용되고 있다. 그러나 높은 잔류응력과 낮은 연성을 가 진 이 소재는 높은 반응성으로 인하여 접합계면에 취성 의 금속간 상과 산화물 상을 형성하기 쉬워 $\mathrm{TiAl}$ 의 접 합을 매우 어렵게 하고 있다. 그러나 고상접합기술은 이러한 문제점을 피할 수 있는 매력적인 기술로 각광받 고 있다. 예를 들어, TiAl과 강은 브레이징(유도와 진 공), 확산 접합과 마찰용접이 시도되고 있다 ${ }^{39)}$.

$\mathrm{TiAl}$ 합금을 접합하는데 브레이징기술은 가장 실현가능 하고 경제적인 방법으로 각광받고 있다. 그러나 $\mathrm{BAlSi}^{-}$ 4 , pure $\mathrm{Ag}$ 와 $\mathrm{BAg} 8$ 를 이용한 브레이징은 $500^{\circ} \mathrm{C}$ 이 상의 온도에서는 낮은 내열성으로 인하여 사용상 어려 움을 겪고 있지만, $\mathrm{Ti}$ 과 $\mathrm{Ni}$ 계 브레이징 합금은 고온에 서 뛰어난 장점을 갖고 있달.

$\operatorname{TiAl}\left(\mathrm{\gamma}^{-T i A l}\right.$ 계) 금속간화합물은 경량 내열재료로 초 점이 맞추어져 왔다 ${ }^{39)}$. 높은 매력을 가진 $\mathrm{TiAl}$ 합금은 가장 중요한 고온 구조재료가 될 전망에 있다. 최근 $\mathrm{TiAl}$ 합금의 성질은 합금설계와 미세조직의 조절로 현저 히 개선되어 가스터빈과 자동차 엔진부품의 소재로도 수요가 기대되고 있다. 그러나 이 소재의 완전한 적용 을 위해서는 브레이징 접합기술이 필수적이다.

$\mathrm{Si}_{3} \mathrm{~N}_{4}$ 세라믹은 안테나용 레이돔(radome)에 차세대 전파-투과(wave-transparent) 재료로 광범위하게 주 
목받고 있으나 $\mathrm{TiAl}$ 로 된 금속홀더와의 브레이징 접합 기술 개발연구 ${ }^{5)}$ 에 시도되었다.

\subsection{Carbon/Carbon 복합재료와 TiAl의 접합}

낮은 밀도와 양호한 고온강도를 지닌 Carbon/ Carbon 복합재료는 고체 로켓모터 노즐과 상부 엔진 노즐에 대 해 매우 이상적인 재료이다. 그러나 $\mathrm{C} / \mathrm{C}$ 복합재료 노 즐의 실제적인 적용을 위해서는 금속홀더에 대한 접합 기술이 필요하다. 여기에 $\mathrm{TiAl}$ 금속간 화합물은 고온에 서의 낮은 밀도, 높은 비강도와 크리프강도로 인하여, 항공기 터빈엔진 부품 내에서 노즐홀더에 기존의 $\mathrm{Ni}$ 계 초내열합금 대신에 $\mathrm{TiAl}$ 소재로의 대체가 가능하다. 그

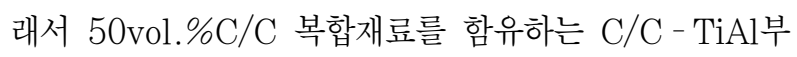
품의 적용은 순수한 $\mathrm{TiAl}$ 부품에 비해서 약 $27 \%$ 나 무 게를 감량할 수 있어, 중량대비 높은 엔진추력을 발휘 할 수 있는 장점이 있다 ${ }^{45)}$.

최근 $\mathrm{C} / \mathrm{C}$ 복합재료의 성공적인 브레이징 접합연구가 추진되었는데, 브레이징 접합부는 브레이징 합금의 낮 은 용융점 때문에 고온에서 사용하는데 적합하지 못하 였다. 아울러 브레이징 합금을 접합조립 하는데 상당히 복잡하고 접합부의 신뢰성을 떨어뜨리는 경향이 있었 다. 그래서 J. $\mathrm{CaO}$ 등 $^{45)}$ 에 의해 $\mathrm{C} / \mathrm{C}$ 복합재료와 $\mathrm{TiAl}$ 의 직접 접합이 바람직하다. 두 물질의 확산접합은 고 온에서 행해야 하고, 반응물은 비교적 낮은 온도에서 점화하여 동시에 연소합성할 수 있다.

매우 높은 고온에서 뛰어난 열 및 기계적 성질로 인 하여 $\mathrm{C} / \mathrm{C}$ 복합재료는 비행기 날개끝부분(wing edges), 원자력반응용기 및 디스크브레이트 등에 사용되고 있 다. $\mathrm{C} / \mathrm{C}$ 복합재료와 $\mathrm{TiAl}$ 의 접합으로 인한 구조체는 응용분야를 확대할 수 있을 것이다.

\section{3 자전연소고온합성법(Self-propagation High- emperature Synthesis, SHS)}

$\mathrm{TiAl}$ 금속간화합물과 $\mathrm{TiC}$ 서멧의 접합은 일반적인 접 합기술로는 상당히 어렵게 인식되고 있으며, 브레이징 과 확산접합은 대부분 진공 혹은 보호가스 중에서 행해 지고 있고, 효율성이 매우 낮아 혁신적인 방법이 요구 되고 있다. 분말 소결체의 자전 고온반응은 에너지의 급속한 연소가 일어나 재료를 접합할 수 있는 국부적인 열원으로 작용한다. 열은 열팽창계수의 차이로 인하여 계면에 국한되어 반응접합이 일어난다. 현재 티타늄, 스 테인리스강, 내열합금을 비롯하여 질화실리콘 및 $\mathrm{NiAl} /$ $\mathrm{FCD}$ (구상흑연주철)에도 성공을 거두고 있다 ${ }^{18)}$.

J. C. Feng 등 ${ }^{18)}$ 은 $\mathrm{TiAl}$ 금속간화합물을 $\mathrm{TiC}$ 서멧
에 SHS공법으로 접합하였다. $\mathrm{Ti}, \mathrm{Al}, \mathrm{C}$ 및 $\mathrm{Ni}$ 분말의 혼합물은 식 $[(1+m) T i+m A l+\mathrm{C}+\mathrm{Ni} \rightarrow m T i A l+$ $\mathrm{TiC}+\mathrm{Ni}$ 의 과정으로 고온합성된다. $\mathrm{Ti}-\mathrm{Al}-\mathrm{C}-\mathrm{Ni}$ 계의 $\mathrm{SHS}$ 반응에서는 $\mathrm{Al}$ 의 용융점에서 점화되어 첫 번 째 반응은 액체 $\mathrm{Al}$ 과 고체 $\mathrm{Ti}$ 사이에 일어나 $\mathrm{TiAl}_{3}$ 로 형성되는데, 온도가 증가함에 따라 $\mathrm{Ti}$ 는 $\mathrm{C}$ 와 반응하여 $\mathrm{TiC}$ 상으로 형성된다.

\section{4 브레이징 합금의 종류}

$\mathrm{Nb}$ 함유 TiAl금속간화합물의 화학성분으로 $\mathrm{Ti}-\mathrm{Al}-\mathrm{Cr}-\mathrm{Nb}$ 계가 선정되고 있는데, J. $\mathrm{CaO}$ 등 $^{29)}$ 과 $\mathrm{P} . \mathrm{He}^{34)}$ 등은 Ti-48Al-2Cr-2Nb(at.\%), L. I. Duarte 등 ${ }^{14)}$ 은 $\mathrm{Ti}^{-}$ $45 \mathrm{Al}-2 \mathrm{Cr}-2 \mathrm{Nb}($ at. $\%)$, Hua-Ping Xiong 등 ${ }^{20)}$ 에 의 해 $\mathrm{Ti}-47 \mathrm{Al}-2 \mathrm{Cr}-1 \mathrm{Nb}\left(\right.$ at.\%), Houqin Wang 등 ${ }^{27)}$ 에 의해 $\mathrm{Ti}-46 \mathrm{Al}-2 \mathrm{Cr}-2 \mathrm{Nb}$ 를 선정하였다. 특히 X. G. Song 등 ${ }^{43)}$ 에 의해 고Nb함유 TiAl합금 $\left(\mathrm{Ti}-45 \mathrm{Al}-5 \mathrm{Nb}^{-}\right.$ (W,B,Y) (at.\%)], T. Tetsui 등 ${ }^{48)}$ 에 의해 Ti-47.1Al$7.8 \mathrm{Nb}-1.0 \mathrm{Cr}-0.5 \mathrm{Si}$, 이 선정되었다. 아울러 $\mathrm{TiAl}$ 계 합금, 특히 $\mathrm{Chen}^{4}$ 에 의해 개발된 고Nb함유 TiAl합금 ( $\mathrm{Ti}-46 \mathrm{Al}-5 \mathrm{Nb})$ 은 자동차산업에서 무게감량을 위해서 내열강과 초내열합금에 대한 매우 전망이 밝은 대체재 료로 고려되고 있다.

$\mathrm{Nb}$ 이 함유되지 않은 $\mathrm{TiAl}$ 금속간화합물의 화학성분으 로 X. G. Song 등 ${ }^{43}$ 에 의해 TiAl합금(Ti-42.5Al-9V$0.3 \mathrm{Y}(\mathrm{at} . \%)$ )이 선정되었고, Peng $\mathrm{He}$ 등 ${ }^{7)}$ 에 의해 $\mathrm{Ti}^{-}$ 46.5Al-9.03V-0.27Y(as cast)이 선정되었고, L. I. Haixin 등 26 에 의해 TiAl(52.82 Al-44.88Ti-1.20Cr-1.10V) 이 선정되었다. 전체적으로 보아, $\mathrm{TiAl}$ 금속간화합물의 화학성분으로 $\mathrm{Ti}-\mathrm{Al}-\mathrm{V}$ 계가 주류를 이루고 있다.

T. Tetsui 등 ${ }^{47-49)}$ 은 Ni계 초내열합금(Inconel 713C) 대신에 TiAl 소재로 대체하여 터보차저에 들어가는 TiAl 터빈 휠을 제조하였다. 특히 저 $\mathrm{Nb}$ 함유 TiAl (Ti-47.3Al$0.4 \mathrm{Nb}$ )보다 고Nb함유 $\mathrm{TiAl}(\mathrm{Ti}-45.0 \mathrm{Al}-7.1 \mathrm{Nb})$ 은 더 욱 우수한 내산화성 (erosion)을 나타내었다.

\section{3. 용가재의 기술개발동향}

\section{1 $\mathrm{Ag}$ 계 용가재}

$\mathrm{Ag}$ 은 $\mathrm{Ti}$ 및 그 합금재료의 브레이징 접합에 사용되 는 대표적인 삽입금속 재료이다. 이 $\mathrm{Ag}-\mathrm{Cu}$ 공정 삽입금 속의 경우, 비교적 낮은 접합온도, 우수한 젖음성과 접 합강도를 나타내는 장점이 있다. 또한 $\mathrm{Ag}-\mathrm{Cu}-\mathrm{Ti}$ 계 합 금의 경우, $\mathrm{Ti}$ 의 활성으로 인하여 접합온도의 감소가 기대되는 삽입금속 재료이다. 구자명 등 ${ }^{9}$ 은 $\mathrm{Ag}-\mathrm{Cu}-\mathrm{Ti}$ 
삽입금속을 사용하여, 접합시간에 따른 TiAl과 AISI 4140 강을 접합특성을 관찰한 후 최적 접합조건을 확립 하였다.

T. Tetsui 등 ${ }^{48)}$ 에 의하면, $\mathrm{BAg}-8$ 과 $\mathrm{BAu}-12$ 용가 재는 $\mathrm{TiAl}(\mathrm{Ti}-47.1 \mathrm{Al}-7.8 \mathrm{Nb}-1.0 \mathrm{Cr}-0.5 \mathrm{Si})$ 과의 젖 음성, 미세조직 및 경도를 평가기준으로 볼 때, $\mathrm{Ti}, \mathrm{Ni}$, $\mathrm{Pd}$ 합금 용가재보다 더욱 우수한 특성을 나타내었다.

P. He 등 ${ }^{34)}$ 은 TiAl계 금속간화합물 ( $\sigma \mathrm{b}: 559$ $668 \mathrm{MPa})$ 을 진공유도 브레이징법으로 $\mathrm{Ag}-\mathrm{Cu}-\mathrm{Ni}-\mathrm{Li}$ 용가재를 이용하여 $35 \mathrm{CrMo}$ 강 $\left(\mathrm{Fe}^{-} 0.35 \mathrm{C}-0.27 \mathrm{Si}^{-}\right.$ $0.55 \mathrm{Mn}-0.1 \mathrm{Cr}-0.2 \mathrm{Mo}(\mathrm{wt} . \%))$ 에 Fig. 1 과 같은 방 법으로 브레이징 접합하였다. 용가재는 $50 \mu \mathrm{m}$ 두께의 Ag-27Cu-1Ni1-0.5Li(wt.\%) foil(øb: 340MPa, 용 융점: $780 \sim 820^{\circ} \mathrm{C}$ )로 선정되었다. $930^{\circ} \mathrm{C}, 1$ 분간 브레 이징한 결과, $324 \mathrm{MPa}$ 을 얻었다. 높은 온도 단시간이 낮은 온도 장시간보다 더욱 유리하였으며, 비평형 결정 의 미세조직이 대부분 관찰되었다.

$\mathrm{P} . \mathrm{He}$ 등 $^{33-36)}$ 에 의해 $\mathrm{TiAl}$ 금속간화합물과 $35 \mathrm{CrMo}$ 강을 $\mathrm{Ag}-27 \mathrm{Cu}-1 \mathrm{Ni}-0.5 \mathrm{Li}$ 용가재와 $\mathrm{Ag}-35.2 \mathrm{Cu}-1.8 \mathrm{Ti}$ 용가재를 이용하여 진공 유도 브레이징한 연구내용을 Table 1에 종합하였다. 브레이징 열처리조건에서 높은 온도 단시간과 낮은 온도 장시간에 대한 차이점을 보이 고 있다.

X. G. Song 등 ${ }^{42)}$ 에 의해 브레이징 접합부의 전단강 도를 향상시키기 위하여 $\mathrm{Ag}-\mathrm{Cu}-\mathrm{Ti}$ 용가재에 $\mathrm{Si}_{3} \mathrm{~N}_{4} \mathrm{p}$ 를 첨가한 영향을 조사한 결과, $\mathrm{TiAl} / \mathrm{AlCu}_{2} \mathrm{Ti}$ 반응층 $/ \mathrm{Ag}(\mathrm{s}, \mathrm{s})+\mathrm{Al}_{4} \mathrm{Cu}_{9}+\mathrm{Ti}_{5} \mathrm{Si}_{3} \mathrm{p}+\mathrm{TiNp} / \mathrm{TiN}+\mathrm{Ti}_{5} \mathrm{Si}_{3}$ 반응 층 $/ \mathrm{Si}_{3} \mathrm{~N}_{4}$ 의 미세구조를 얻었으며, Fig. 2 에서 보는 바 와 같이 $\mathrm{Si}_{3} \mathrm{~N}_{4} \mathrm{p}$ 함량이 $3 \mathrm{wt} . \%$ 인 경우에 최고 전단강도 를 나타내었다.

X. G. Song 등 ${ }^{42)}$ 에 의해 비활성 $\mathrm{AgCu}$ 용가재를 이용하여 $\mathrm{TiAl}$ 금속간화합물을 $\mathrm{Si}_{3} \mathrm{~N}_{4}$ 세라믹과의 접합 을 시도한 결과, 접합계면의 미세구조는 $\mathrm{TiAl} / \mathrm{B}_{2}$ 상/ $\mathrm{AlCuTi} / \mathrm{AlCu}_{2} \mathrm{Ti} / \mathrm{Ag}(\mathrm{s}, \mathrm{s})+\mathrm{AlCu}_{2} \mathrm{Ti} / \mathrm{TiN}+\mathrm{Ti}_{5} \mathrm{Si}_{3} /$ $\mathrm{Si}_{3} \mathrm{~N}_{4}$ 이었으며, 브레이징온도가 증가함에 따라 중심부 의 입상 $\mathrm{AlCu}_{2} \mathrm{Ti}$ 금속간화합물의 분포가 변하였고, 질
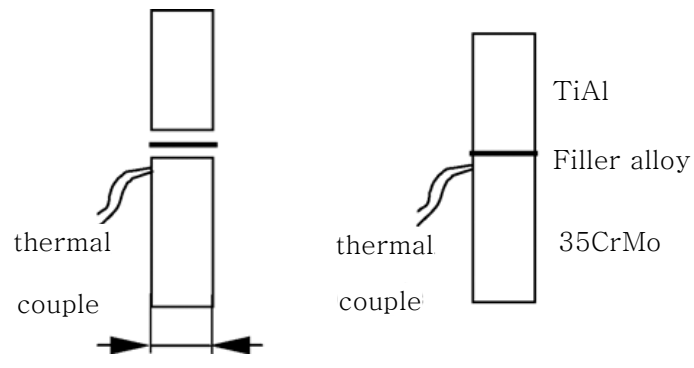

Fig. 1 Sketch map of the brazed TiAl/steel joint $^{34)}$
Table 1 Brazing conditions of TiAl intermeallics and steel $35 \mathrm{CrMo}^{33-36)}$

\begin{tabular}{|c|c|c|c|c|}
\hline Filler metal & $\begin{array}{c}\text { Brazing } \\
\text { temp. }\end{array}$ & $\begin{array}{c}\text { Brazing } \\
\text { time }\end{array}$ & $\begin{array}{c}\text { Tensile } \\
\text { strength }\end{array}$ & $\begin{array}{c}\text { Optimal } \\
\text { condition }\end{array}$ \\
\hline $\mathrm{Ag}-\mathrm{Cu}-\mathrm{Ni}-\mathrm{Li}$ & $\begin{array}{c}920 \sim \\
930^{\circ} \mathrm{C}\end{array}$ & $1 \sim 2 \mathrm{~min}$. & $324 \mathrm{MPa}$ & $\begin{array}{c}930^{\circ} \mathrm{C}, \\
1 \mathrm{~min} .\end{array}$ \\
\hline $\mathrm{Ag}-\mathrm{Cu}-\mathrm{Ti}$ & $\begin{array}{c}870 \sim \\
880^{\circ} \mathrm{C}\end{array}$ & $4 \sim 6 \mathrm{~min}$. & $320 \mathrm{MPa}$ & $\begin{array}{c}870^{\circ} \mathrm{C}, \\
5 \mathrm{~min} .\end{array}$ \\
\hline
\end{tabular}

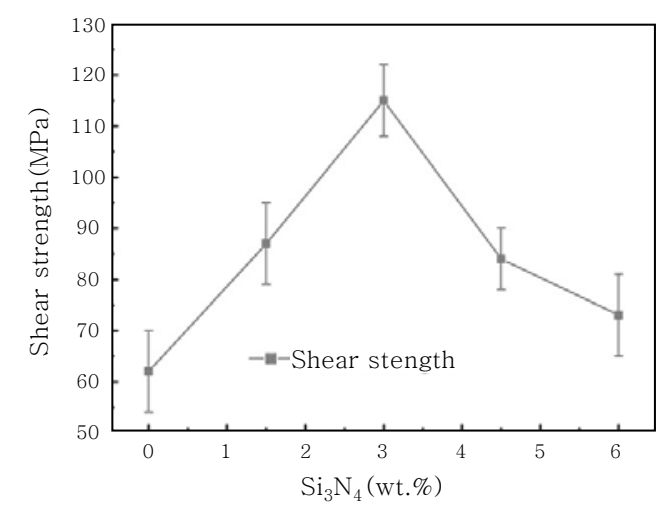

Fig. 2 Effect of $\mathrm{Si}_{3} \mathrm{~N}_{4 \mathrm{p}}$ content on shear strength of brazed joints ${ }^{42)}$

화실리콘기판에 인접한 $\mathrm{TiN}+\mathrm{Ti}_{5} \mathrm{Si}_{3}$ 층의 두께가 증가 하였다. $860^{\circ} \mathrm{C}$ 에서 5 분간 브레이징 하여 $124.6 \mathrm{MPa}$ 의 전단강도를 얻었으며, $\mathrm{AlCu}_{2} \mathrm{Ti}$ 상의 석출을 위한 작 은 $\mathrm{Al}_{3} \mathrm{~V}$ 금속간화합물의 핵생성으로 인하여 접합부 품 질특성을 향상시켰음을 확인하였다.

Yulong $\mathrm{Li}$ 등 ${ }^{17)}$ 은 엔진터보부품인 터빈로터에 적용 하기 위하여 TiAl과 $42 \mathrm{CrMo}$ 강을 $\mathrm{Ag}-\mathrm{Cu} / \mathrm{Ti} / \mathrm{Ag}-\mathrm{Cu}$ 용가재로 진공 브레이징하였다. $500^{\circ} \mathrm{C}$ 에서 5 분간 브레 이징한 경우, $347 \mathrm{MPa}$ 과 $229 \mathrm{MPa}$ 의 상온 인장강도와 전단강도를 달성하였다.

Zhenwen Yang 등 ${ }^{5}$ 은 $\mathrm{TiAl}$ 합금을 $\mathrm{C} / \mathrm{SiC}$ 복합재 료에 $\mathrm{Ag}-\mathrm{Cu}$ 용가재를 이용하여 진공브레이징한 결과, 브레이징 접합부의 품질은 $\mathrm{TiC}$ 층과 $\mathrm{AlCu}_{2} \mathrm{Ti}$ 상의 형성 에 가장 큰 영향을 미쳤는데, 균열은 주로 $\mathrm{Ag}$-rich상 과 $\mathrm{TiC}$ 층을 따라 진전하였다. $950^{\circ} \mathrm{C}$ 에서 10 분간 진공 브레이징 시에 $\mathrm{TiC}$ 층 두께가 $4 \sim 5 \mu \mathrm{m}$ 인 경우 $85 \mathrm{MPa}$ 의 최고 전단강도를 나타내었다.

Houqin Wang 등 ${ }^{27)}$ 은 $\mathrm{Ag}-26.7 \mathrm{Cu}-4.6 \mathrm{Ti}$ 용가재를 이용하여 브레이징 하였으며, 또한 $\mathrm{C} / \mathrm{C}$ 표면에 구멍을 형성시키는 방법으로 infiltration 강화효과를 검토하였 다. 이러한 구멍들은 $0.8 \mathrm{~mm} \phi$ 의 바늘에 의해 드릴링 되 었으며, $3 \mathrm{~mm}$ 폭의 4 각형 구조로 배열시켰으며 $1 \mathrm{~mm}$, $3 \mathrm{~mm}$ 의 깊이로 하였다. 펀치 후 구멍은 $\mathrm{C} / \mathrm{C}$ 복합재료 의 탄성회복으로 인한 작은 공간(gap)이 되었으며, 브 레이징 동안에 용가재의 모세관 작용을 증진시켰다. 또 


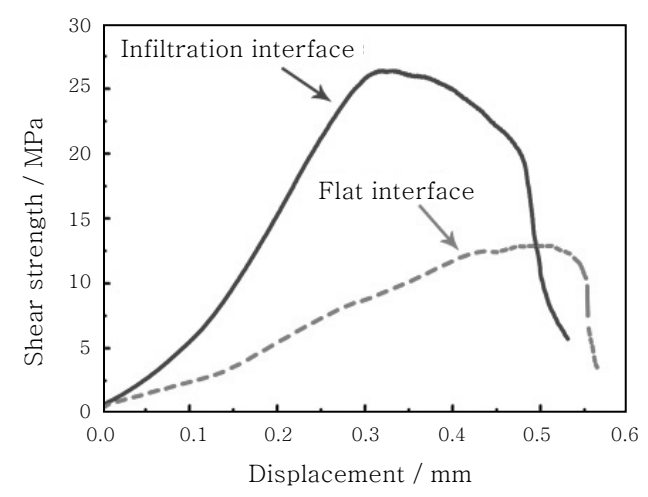

Fig. 3 Effect of interfacial shape on shear strength ${ }^{27)}$

한 infiltration 강화효과로 전단강도는 Fig. 3에서 보 는 바와 같이 획기적으로 향상시킬 수 있었다.

\subsection{Ti계 용가재}

$\mathrm{TiAl}$ 금속간화합물을 브레이징 하는데 $\mathrm{Wu}$ 등 $^{9)}$ 은 $\mathrm{Ti}$ 계, $\mathrm{Ag}$ 계, $\mathrm{Al}$ 계 용가재를 비교한 결과, $\mathrm{Ti}$ 계 용가재는 더욱 양호한 고온 거동을 나타내었다. Ti계 용가재 포 일은 기판의 형태가 복잡할 때에는 제한이 있으나 분말 은 적용범위가 더욱 광범위하기 때문에 분말소재에 대 한 활용도가 높다. 용가금속 분말을 제조하는 방법가운 데 기계적 밀링에 관한 제조법 ${ }^{7}$ 이 가장 선호되어 입자 미세화, 화학성분의 변화, 양호한 젖음성(wettability) 의 관점에서 추진되어 왔다.

$\mathrm{Ti}-\mathrm{Ni}$ 용가재의 용융점은 수요가의 기대치보다 높아 용융점을 낮추기 위하여 $\mathrm{Ti}-\mathrm{Ni}$ 계 내에 $\mathrm{Si}$ 첨가의 영향 을 조사하였달) J. $\mathrm{Cao}$ 등 ${ }^{8)}$ 은 $\mathrm{Si}$ 첨가는 접합부의 중 간에 $\mathrm{Ti}$ 을 집합(aggregation)시키고 $\mathrm{Ti}_{3} \mathrm{Al}$ 상을 형성시 키는 역할을 함을 관찰하였다.

브레이징 온도를 낮추고 양호한 품질의 $\mathrm{Ti}-\mathrm{Al}$ 금속간 소재를 접합하기 위한 TiNi분말 용가재를 Peng $\mathrm{He}$ 등7)에 의해 개발되었다. 아르곤가스 분위기 중에서 120 분 동안 기계적 밀링을 한 $\mathrm{TiH}_{2}-50 \mathrm{wt} \% \mathrm{Ni}$ 분말 합금을 용가재로 $1180^{\circ} \mathrm{C}$ 에서 15 분 동안 진공 노 (furnace) 브레이징 접합한 결과, 가장 높은 전단강도 를 얻을 수 있었다.

L. I. Duarte 등 ${ }^{14)}$ 은 용가재로서 $\mathrm{Ti}$ 과 $\mathrm{Al}$ 을 나노단위 $(2 \mu \mathrm{m})$ 의 층으로 교대로 적층하여 $\mathrm{TiAl}$ 을 계면의 화학적 인 불연속 없이 서로 접합(dcmagnetron sputtering)시 킨 결과, 약 $1000^{\circ} \mathrm{C}$ 에서 결함이 없는 양호한 나노결정 조직을 얻을 수 있었다.

$\mathrm{TiAl}$ 과 $\mathrm{Ni}$ 계 합금에 대해 Tetsui 등 ${ }^{22)}$ 은 $\mathrm{Ag}$ 계 용가 재로 브레이징 접합하였으나, 이 접합은 $500{ }^{\circ} \mathrm{C}$ 이상의 브레이징 용가재의 고온품질 부족으로 접합에는 만족하
지 못하였다. 이에 대비하여 FAN Kun ${ }^{23)}, \mathrm{P} . \mathrm{He}^{24)}$ 등에 의해 $\mathrm{Ti}-\mathrm{Ni}$ 계 용가재 $\left(942^{\circ} \mathrm{C}\right.$ 이상의 용융점 $)$ 가 개발되어 고온강도를 확보하였다. 특히 Duan Huiping 등 ${ }^{25)}$ 에 의해 삽입금속으로 $\mathrm{TiNi}$ 계 브레이징합금 을 용가재로 이용하여 전이(transient) 액상 접합기술 을 적용하여 TiAl과 Inconel 718을 접합하였는데 조 직과 기계적 성질에 관한 세부적인 자료는 확보하지 못 했다.

L. I. Hai-xin 등 ${ }^{26)}$ 에 의해 $\operatorname{TiAl}\left(52.82 \mathrm{Al}-44.88 \mathrm{Ti}^{-}\right.$ $1.20 \mathrm{Cr}-1.10 \mathrm{~V})$ 와 $\mathrm{GH} 99\left(57.29 \mathrm{Ni}^{-}-20.63 \mathrm{Cr}^{-} 7.46 \mathrm{Co}^{-}\right.$ $5.44 \mathrm{Al}-3.03 \mathrm{~W}-2.98 \mathrm{Mo}-1.96 \mathrm{Ti}$ )을 Ti박판(foil)을 이 용하여 $1000^{\circ} \mathrm{C}$ 에서 10 분간 브레이징한 결과, 최고 전 단강도는 $258 \mathrm{MPa}$ 에 도달하였으나, 브레이징 온도가 높거나 시간이 더 길면 접합부 상의 조대화가 일어나 취성의 금속간 층이 형성되어 전단강도는 급격히 떨어 졌다.

$\mathrm{RIP}$ (rapid isothermal process)의 일종인 매우 빠 르고 값싼 적외선 접합방법을 사용하여 S. J. LEE 등 ${ }^{37)}$ 은 아르곤분위기에서 $1100 \sim 1200^{\circ} \mathrm{C}$ 의 온도범위에 서 30 60초 동안 $\mathrm{TiAl}$ 을 적외선 접합하는데, $\mathrm{Ti}^{-}$ $15 \mathrm{Cu}-15 \mathrm{Ni}(\mathrm{wt} \%)$ foil을 이용하였다.

X. G. Song 등 ${ }^{43)}$ 에 의해 고Nb함유 $\mathrm{TiAl}$ 합금 $\left(\mathrm{Ti}^{-}\right.$ $45 \mathrm{Al}-5 \mathrm{Nb}-(\mathrm{W}, \mathrm{B}, \mathrm{Y})(\mathrm{at} . \%))$ 에 대하여 $\mathrm{TiNi}-\mathrm{Nb}$ 공정 브레이징합금 $(40 \mathrm{Ti}-40 \mathrm{Ni}-20 \mathrm{Nb}$ (at.\%))을 이용하여 진 공아크 재용해법으로 브레이징 접합한 결과, $\mathrm{O}-\mathrm{Ti}_{2} \mathrm{AlNb}$ 와 $\tau_{3^{-}} \mathrm{Al}_{3}(\mathrm{Ti}, \mathrm{Nb})_{2} \mathrm{Ni}$ 의 새로운 금속간 상을 관찰하였 으며, $1220^{\circ} \mathrm{C}$ 에서 10 분간 열처리하여 $308 \mathrm{MPa}$ 의 상 온 전단인장강도를 달성하였다.

X. G. Song 등 ${ }^{46}$ 에 의해 TiAl합금(Ti-42.5Al-9V$0.3 \mathrm{Y}(\mathrm{at} . \%)$ )에 대하여 $\mathrm{TiNi}-\mathrm{V} 25(\mathrm{at} . \%)$ 의 공정 브레 이징합금을 이용하여 $1220^{\circ} \mathrm{C}$ 에서 10 분간 열처리한 결 과, $196 \mathrm{MPa}$ 의 가장 높은 전단인장강도를 얻었다. 브 레이징 접합부는 $\mathrm{B} 2$ 상과 $\tau_{3}-\mathrm{Al}_{3} \mathrm{Ni} \mathrm{Ti}_{2}$ 금속간상은 취 성으로 인한 접합부 성질에 해를 끼치는 것으로 확인되 었다.

$\mathrm{TiAl}$ 판은 가스터빈에 $\mathrm{Ni}$ 합금과 강 대신에 $\mathrm{TiAl}$ 판을 대체재로 적용하면 무게를 $40 \%$ 까지 절감할 수 있었다. I. C. Wallis 등 ${ }^{44)}$ 은 $\mathrm{Ti}-\mathrm{Cu}-\mathrm{Ni}$ 브레이징합금을 용가 재로 선정하여 $\gamma^{-} \mathrm{TiAl}$ 을 접합한 결과, 양호한 품질의 고강도 접합부를 얻을 수 있었다.

Z. W. Yang 등 ${ }^{11)}$ 에 의해 $\mathrm{TiB}$ 위스커(30\%)로 강 화된 $\mathrm{C} / \mathrm{SiC}$ 복합재료와 $\mathrm{TiAl}$ 을 $\mathrm{Ti}-\mathrm{Ni}-\mathrm{B}$ 브레이징합금 용가재로 하여 브레이징 용접하였다. 아크용융법으로 제 조된 $\mathrm{Ti}-\mathrm{Ni}-\mathrm{B}$ 브레이징합금 $\left(\right.$ 용융점 $\left.1120^{\circ} \mathrm{C}\right)$ 의 강화요 인은 $\mathrm{TiNi}, \mathrm{TiNi}_{3}$ 및 $\mathrm{TiB}_{2}$ 상에 의한 것이며, $\mathrm{TiAl}$ 과 
$\mathrm{C} / \mathrm{SiC}$ 복합재료의 접합은 $1160^{\circ} \mathrm{C}$ 에서 10 분간 열처리 하여 브레이징접합한 결과, 상온과 $600^{\circ} \mathrm{C}$ 에서 평균 전 단강도는 각각 $90 \mathrm{MPa}$ 과 $65 \mathrm{Mpa}$ 에 달하였다.

Hai-xin LI 등 ${ }^{10)}$ 에 의해 TiAl계 금속간화합물과 $\mathrm{Ni}$ 계 합금에 대하여 삽입층으로서 $\mathrm{Ti}$ 계를 적용하여 100 $0^{\circ} \mathrm{C}$ 에서 10 분간 브레이징한 결과, 최고 전단강도는 $258 \mathrm{MPa}$ 을 나타내었으나, 브레이징온도가 높거나 시간 이 길면 브레이징 심부에 상(phases)의 조대화를 일으 켜 접합부의 전단강도가 크게 저하하였다.

R. K. Shiue 등 6$)$ 에 의해 $\mathrm{Ti}-15 \mathrm{Cu}-(15 \sim 25) \mathrm{Ni}$ 브 레이징 합금을 이용하여 $\mathrm{Ti} 50-\mathrm{Al} 50$ 과 $\mathrm{Ti}-6 \mathrm{Al}-4 \mathrm{~V}$ 을 적외선 브레이징한 결과, $970^{\circ} \mathrm{C}, 10$ 분 이상에서 가장 양호한 접합강도를 나타내었다. 접합부에는 주로 $\mathrm{Ti}^{-}$ rich, $\mathrm{Ti}_{2} \mathrm{Ni}$ 및 계면에 $\mathrm{Ti}_{3} \mathrm{Al}$ 상이 관찰되었는데, 특히 $\mathrm{Ti}_{2} \mathrm{Ni}$ 상과 브레이징 냉각도중에 계면에 발생되는 $\mathrm{Ti}_{3} \mathrm{Al}$ 상은 접합부의 전단강도를 해치는 것으로 확인되었다.

J. Cao 등 29$)$ 은 $\mathrm{Ti}-\mathrm{Al}-\mathrm{C}$ 중간층을 이용하여 $\mathrm{TiAl}$ 금속간화합물을 반응제조하였다. $\mathrm{Ti}$ 분말과 $\mathrm{Al}$ 분말의 화학적 결합은 낮은 네거티브 엔털피를 나타내지만 $\mathrm{C}$ 분말의 첨가로 인하여 강한 발열반응을 일으켜 식 $[(\mathrm{m}+1) \mathrm{Ti}+\mathrm{mAl}+\mathrm{C} \rightarrow \mathrm{mTiAl}+\mathrm{TiC}]$ 과 같은 활성적인 화학양론적 반응으로 $\mathrm{TiAl}$ 금속간화합물이 생 성된다. J. Cao 등 ${ }^{29)}$ 은 $\mathrm{TiAl}$ 금속간화합물을 분말혼합 물 혹은 복합층 포일에 의해서 제조된 $50 \mathrm{Ti}-(33$ 39) $\mathrm{Al}-(11 \sim 17) \mathrm{C}(\mathrm{at} . \%)$ 를 중간층으로 하여 단열 (adia- batic) 온도를 이용하여 브레이징 접합하였다. 반응열이 증가함에 따라 접합부의 품질은 향상되었으나 반응열이 너무 높으면 접합부의 품질과 제품의 밀도는 오히려 감소되는 현상을 보였다. 단열온도가 $2218^{\circ} \mathrm{C}$ 인 경우 $50 \mathrm{Ti}-35 \mathrm{Al}-15 \mathrm{C}(\mathrm{at} . \%)$ 합금에서 최고 접합강도 를 얻을 수 있었다.

\section{3 기타 용가재}

H. P. Xiong 등 ${ }^{19)}$ 은 TiAl금속간화합물에 순 알루미 늄을 접합하는데 $\mathrm{Si}$ 함유 $\mathrm{Al}$ 계 브레이징합금을 용가재로 사용하였다. TiAl 표면에 $\mathrm{Si}$ 이 강하게 확산되어 들어가 친화력을 상당히 크게 함으로써 내산화력향상에 크게 기여하였다.

\section{4. 국내 연구현황}

NDSL검색결과, 국내에서는 최근 10 년간 95 건이 게 재되어 있어 $\mathrm{TiAl}$ 소재에 대한 연구는 매우 활성화되어 있으나 브레이징에 관한 연구실적 ${ }^{9)}$ 이 1건 정도 게재되 어 있어, 향후 국내에도 브레이징 접합연구의 활성화가
절실히 요구되고 있다. 구자명 등ํ에 에하면, TiAl과 AISI 4040강의 접합 시에 $\mathrm{Ag}-\mathrm{Cu}-\mathrm{Ti}$ 삽입금속을 이 용하여 $800^{\circ} \mathrm{C}$ 에서 60 초간 브레이징한 결과, 모재강도 의 $70 \%$ 인 $296 \mathrm{MPa}$ 의 최대 인장강도를 얻었다. 사용 된 삽입금속은 Lucas-Milhaupt사의 두께가 $100 \mu \mathrm{m}$ 인 Cerametil 721로 선정되었으며, Ag-rich, Ti-rich, CuTi 와 $\mathrm{CuTi}_{2}$ 로 이루어졌음이 관찰되었다.

\section{5. 향후 기술전망}

\section{1 경제적 제조기술}

브레이징 접합은 형상과 크기의 제한이 거의 없고 정 밀한 접합이 가능하며, 상대적으로 낮은 접합온도에서, 한 공정으로 여러 접합부를 동시에 접합이 가능한 장점 이 있다. 특히 $\mathrm{TiAl}$ 의 응용범위를 확대하기 위하여 간 단한 형상에서부터 복잡한 형상에까지 구분하여 경제적 으로 생산할 수 있는 접합기술이 요구되고 있어 향후 국내에서도 이에 대한 연구가 활성화될 것이다.

$\mathrm{TiAl}$ 과 관련된 접합기술들은 진공브레이징을 포함하 는 브레이징 접합, 삽입금속을 이용한 적외선 용접, 마 찰용접, 확산 붙임, 전자빔 용접과 같은 복합용접, 그리 고 전기방전용접 등이 전개되고 있다 ${ }^{41)}$. 이중 경제성과 품질이 복합된 최적의 방법을 찾아내는 것이 중요한 과 제이다.

$\mathrm{TiAl}$ 이 활성물질이기 때문에 진공상태에서 $\mathrm{TiAl}$ 과 구조용강의 접합이 용이하게 실시되고 있으나, 특히 자 동차산업에서 진공 브레이징은 높은 비용 때문에 비실 용적이다. 그래서 향후 낮은 비용과 높은 강도를 얻는 기술을 개발하기 위하여, 열처리속도가 빠르고 효율성 과 생산성이 높은 빠른 유도브레이징 기술이 활발하게 추진될 수 있을 것으로 예상된다.

적외선 브레이징법은 브레이징온도를 낮추고 시간을 절약할 수 있고, 적외선을 국부적으로 시편에 가열할 수 있고 로의 나머지부분에 대한 열량소비를 피할 수 있다. 따라서 적외선가열은 높은 에너지효율을 지닌 전 망이 밝은 방법 ${ }^{12)}$ 으로 내다보고 있다. 특히 사용에너지 를 획기적으로 절감할 수 있으므로 향후 산업분야에 적 용의 확대가 기대된다.

값비싼 $\mathrm{Ag}$ 계 용가재 대신에 $\mathrm{Ti}$ 계 용가재로 브레이징 하는 연구가 활성화될 것으로 예상되며, 향후 다른 금 속에 대한 브레이징 적용연구가 확대될 것으로 예상된다.

\section{2 품질향상기술}

$\mathrm{TiAl}$ 소재의 브레이징성을 향상시키기 위해서는 다음 
과 같은 공법 ${ }^{38)}$ 으로서 첫째, 접합되어야 할 재료 사이 에 삽입되는 중간층의 형태(예, 분말, foil) 화학성분(예, $\mathrm{Ag}$ 계, $\mathrm{Ti}$ 계), 두께에 대한 최적의 종합적인 설계가 필 수적이다. 둘째, 브레이징 시에 고온에서의 유지시간은 재료(모재 및 중간층), 요구되는 접합부 성질 등에 따 라 몇분에서 몇시간이 걸릴 수 있다. 브레이징 온도의 높낮이를 조절하여 최적의 유지시간에 대한 설정연구가 활발히 전개될 것이다. 셋째, 확산브레이징의 경우에는 거시적 변형을 방지하기 위하여 보통 3 10MPa의 낮은 압력이 사용된다. 그러나 $\mathrm{HIP}$ (hot isostatic pressing) 에서는 더 높은 압력 $(200 \mathrm{MPa})$ 이 사용된다. 이 경우 표면마무리가공 정도는 단축의 경우에서와 같이 결정적 인 영향은 미치지 않으므로 유리한 측면이 있어, 이에 대한 연구개발이 선호될 수 있을 것이다. 넷째, $8-\mathrm{TiAl}$ 합금의 고상 확산접합시 스퍼터링공법으로 $\mathrm{Ti} / \mathrm{Al}$ 복합 층의 박막(foil)으로 나노결정구조를 형성시킨다. 이 방 법은 접합되어야 할 표면의 확산도와 반응성을 높일 수 있는 효과가 있으며 중간층과 재료 사이의 불연속 (disruption)을 피할 수 있는 장점이 있으므로 이러한 공법이 활성화 될 것이다. 다섯째, 삽입층으로 적용되 는 금속 복합층의 발열특성은 $\gamma^{-T i A l}$ 상에 대한 박막 의 열발생에 대한 활용은 접합공정에 요구되는 에너지 의 감소에 기여하므로 이에 대한 연구의 활성화가 예상 된다.

$\mathrm{TiAl}$ 소재와 강의 접합은 일례로, 미사일과 탱크엔진 터보부품의 접합에 적용할 수 있으나, 심한 고온균열의 발생경향과 취성의 금속간화합물을 형성으로 인하여 생 산에 어려움이 있으므로 이에 대한 해결책이 모색될 것 이다 ${ }^{34)}$

$\mathrm{TiAl}$ 계 합금과 강은 $\mathrm{Ag}$ 계 용가재를 이용하여 브레이 징한 실적은 있지만 고강도를 제시할 수 있는 브레이징 접합부의 최적의 조건을 제시하는데 미흡하였다. 일례 로 $\mathrm{Ag}-\mathrm{Cu} / \mathrm{Ti} / \mathrm{Ag}-\mathrm{Cu}$ 용가재로 시도하여 고강도의 접 합부를 성취하였다. ${ }^{17)}$ 향후 최적의 품질을 나타낼 수 있는 용가재를 개발하는 연구가 추진될 것이다.

기존의 확산접합 공정 ${ }^{22}$ 은 $\mathrm{TiAl} /$ 강의 접합부 계면에 $\mathrm{FeAl}, \mathrm{FeAl}_{2}$ 및 $\mathrm{TiC}$ 의 금속간화합물을 형성하여 최고 인장강도가 $170 \sim 185 \mathrm{MPa}$ 에 머물고 있으며, 종래의 진공브레이징법에서는 가열속도가 보통 $50^{\circ} \mathrm{C} / \mathrm{min}$. 이 하로 느려서 바람직하지 못한 것으로 판단된다. 이에 대비하여 유도 진공브레이징 ${ }^{29-31)}$ 은 최고 가열속도가 $3000^{\circ} \mathrm{C} / \mathrm{min}$. 만큼 높아 대량생산이나 복잡한 부품의 생산에 매우 유리한 것으로 판단된다. 기존의 진공브레 이징 기술을 탈피한 유도 진공브레이징 방식에 대한 연 구가 활성화 될 것으로 예상된다.
$\mathrm{TiAl}$ 소재는 낮은 밀도를 가진 고온강도로 인하여 항 공 및 자동차 재료로 각광을 받고 있으나 상온에서의 불충분한 연성과 $800^{\circ} \mathrm{C}$ 이상에서의 내산화성이 충분하 지 않다 ${ }^{40)}$. 그래서 브레이징한 후에도 TiAl합금의 내산 화성을 향상시키기 위하여 이온주입법, 마그네트론 스 퍼터링, PVD, 플라즈마용사법, Siliconizing과 같은 표면개질에 관한 연구가 주로 시도될 수 있을 것이다.

\section{3 브레이징 온도의 감소기술}

브레이징온도가 높거나 시간이 길면 브레이징 심부에 상(phases)의 조대화를 일으켜 접합부의 전단강도가 크게 저하하므로 ${ }^{10)}$ 최적의 브레이징온도와 시간에 대한 설정연구가 필수적이다. 최고전단강도를 얻기 위해서는 가장 적당한 브레이징온도의 시간의 파악이 중요하다. 일례로 $\mathrm{Ti}-\mathrm{Ni}$ 용가재에 $\mathrm{Si}$ 을 첨가하여 용가재의 용융 점을 낮추는 연구가 활성화될 것으로 예상된다.

브레이징 접합 시에 접합온도의 감소연구가 활발히 진행될 것이다. $\mathrm{Ag}-\mathrm{Cu}$ 공정 (eutectic) 삽입금속의 경 우, 비교적 낮은 접합온도, 우수한 젖음성과 접합강도 를 나타내는 장점이 있다. 예를 들면, $\mathrm{Ag}-\mathrm{Cu}-\mathrm{Ti}$ 계 합 금의 경우 ${ }^{9)}, \mathrm{Ti}$ 의 활성으로 인하여 접합온도의 감소가 기대되는 삽입금속 재료이다.

브레이징 온도와 유지시간이 낮을수록 전단강도가 낮 다. 반면에 브레이징 시간이 증가할수록 두꺼운 입계층 (interfacial layer)의 형성으로 전단강도가 급격히 감 소하는 경향이 있어 최적의 브레이징 온도와 브레이징 시간의 파악이 품질향상에 중요한 부분을 차지할 것으 로 사료된다 ${ }^{8,10)}$.

종래의 일반적인 진공로 브레이징과 비교해서 적외선 진공브레이징은 $3000^{\circ} \mathrm{C} / \mathrm{min}$. 의 매우 빠른 열이력을 장점으로 하고 있다. 그러므로 브레이징 온도와 시간의 단축으로 인하여 계면반응의 감소, 에로젼부식성의 저 하, 모재금속 성질의 최소손실을 가져온다 ${ }^{41)}$. 향후 적 외선 진공브레이징 기술의 확대가 활성화될 것이다.

\section{4 취성 및 균열 방지기술}

$\mathrm{TiAl}$ 계 금속간 합금은 심한 저온취성과 높은 균열감 수성을 안고 있으므로 종래의 용융용접기술로서는 만족 할만한 접합부를 얻을 수 없다. 건전한 접합부를 얻기 위해서는 초소성 성형/확산 접합, 반응유기 확산접합과 같은 고상 확산접합법 ${ }^{21)}$ 으로 가능하다. 그러나 이러한 공정은 복잡하고 공정시간이 길고 고압이 요구되어 실 제 생산에는 적합하지 않다. 그러나 확산접합 ${ }^{16)}$, 브레 이징 ${ }^{15)}$ 및 확산 브레이징 ${ }^{14)}$ 과 같은 고상용접기술은 
$\mathrm{TiAl}$ 합금의 응고균열에 대한 문제를 해결할 수 있을 것 이다.

TiAl과 구조용강에 적용되는 접합기술로서는 향후 진 공 브레이징과 마찰용접이 주로 거론될 수 있을 것이 다. 그러나 TiAl과 강의 마찰용접은 접합 후의 냉각에 서 구조용강의 마르텐사이트 변이에 의한 내부응력의 증가로 인해 접합부의 취성인 경계에서의 균열 때문에 어려움을 겪고 있어, 취성균열의 방지에 브레이징 접합 기술이 더욱 선호될 것이다.

진공브레이징 접합부의 품질은 $\mathrm{TiC}$ 층의 형성에 가장 큰 영향을 미치는 것으로 알려져 있는데, 균열은 주로 $\mathrm{Ag}-\mathrm{rich}$ 상과 $\mathrm{TiC}$ 층을 따라 진전하므로, 균열의 방지에 는 $\mathrm{TiC}$ 층의 감소가 가장 중요한 인자로 고려되고 있다. 향후 이러한 인자들에 대한 관심은 취성균열 방지에 대 한 도움이 될 수 있을 것이다.

\section{5 응용분야의 확대}

최근 $\mathrm{TiAl}$ 의 용융용접, 확산접합, 브레이징, 마찰접 합에 대한 연구가 활발하게 진행되고 있다. 특히 브레 이징 접합은 형상과 크기의 제한이 거의 없고 정밀한 접합이 가능하며 상대적으로 낮은 접합온도에서, 한 공 정으로 여러 접합부를 동시에 접합이 가능한 장점이 있 다. 일례를 들어서 $\mathrm{TiAl}$ 과 강의 접합은 우수한 내마모 특성과 인성을 부여함과 동시에 더 크고 더 복잡한 구 조물을 제작하기 위하여 필수적인 공정이다.

$\mathrm{TiAl}$ 금속간 합금은 우주항공산업와 자동차 산업에서 터빈블레이드, 배기밸브 및 터보차저 로터와 같은 분야 에 적용이 성공적으로 시도되고 있다. 향후 항공기 터 빈엔진, 기체 (airframe)과 자동차의 엔진과 같은 부분 의 초내열합금에 대한 대체 가능성을 검토하고 한다. 특히 TiAl은 미래의 환경친화적 자동차용 고온 부품을 개발하기 위한 신소재로 자동차 내열부품의 개발에 이 바지할 것이다.

최근 $\mathrm{TiAl}$ 의 용융용접, 확산접합, 브레이징, 마찰접 합에 대한 연구가 활발하게 진행되고 있다. 특히 브레 이징 접합은 형상과 크기의 제한이 거의 없고 정밀한 접합이 가능하며, 상대적으로 낮은 접합온도에서 한 공 정으로 여러 접합부를 동시에 접합이 가능한 장점이 있 다. 일례를 들어서 $\mathrm{TiAl}$ 과 강의 접합은 우수한 내마모 특성과 인성을 부여함과 동시에 더 크고 더 복잡한 구 조물을 제작하기 위하여 필수적인 공정이다.

$\mathrm{TiAl}$ 금속간 합금은 우주항공산업과 자동차 산업에서 터빈블레이드, 배기밸브 및 터보차저 로터와 같은 분야 에 적용이 성공적으로 시도되고 있다 ${ }^{28)}$. 향후 항공기 터빈엔진, 기체(airframe)와 자동차의 엔진과 같은 부
분의 초내열합금에 대한 대체 가능성을 검토하여야 한 다. 특히 TiAl은 미래의 환경친화적 자동차용 고온 부 품을 개발하기 위한 신소재로 자동차 내열부품의 개발 에 이바지할 것이다.

감마(§)-TiAl은 고강도, 낮은 밀도, 양호한 내산화성 을 인하여 최고의 추진중량비(Thrust/weight)와 높은 사용온도에 대한 품질을 보증해야 하는 극초음속 비행체 (hypersonic vehicle)에 적합한 소재, 즉, 극초음속 엔 진 내에 있는 대형의 정적 구조체 부품으로 적합한 재료로 판명되고 있다. 향후 설계방법론(design methodology), 제조기술, 유한요소 분석 및 요구되는 재료의 특성에 대한 기술개발이 활성화 될 것이다 ${ }^{13)}$.

\section{6. 결 론}

1) $\mathrm{TiAl}$ 소재는 높은 반응성으로 인하여 접합계면에 취성의 금속간 상과 산화물 상을 형성하기 쉬워 접합을 매우 어렵게 하고 있으나, 브레이징 접합기술은 이러한 문제점을 피할 수 있는 가장 실현가능하고 경제적, 효 과적인 기술로 각광받고 있다.

2) $\mathrm{TiAl}$ 금속간화합물은 미래의 환경친화적 내열 신 소재로 우주항공산업, 자동차산업 등에 적용이 활성화 될 것으로 예상된다. 이에 부응하여 $\mathrm{TiAl}$ 의 브레이징성 향상을 위한 제조조건을 확립하기 위해서는 $\mathrm{Ag}$ 계와 $\mathrm{Ti}$ 계 용가재를 이용한 브레이징 접합기술의 국내기술의 정착이 시급한 과제로 대두되고 있다.

3) 국내에서는 $\mathrm{TiAl}$ 소재에 비해 브레이징접합에 관 한 연구는 매우 부진한 실정에 있으므로 향후 국내에서도 브레이징 접합연구의 활성화가 절실히 요구되고 있다.

4) 5-10년 후 예측되는 기술로서 경제적 제조기술, 품질향상기술, 브레이징 온도의 감소기술, 취성 및 균 열 방지기술이 있으며, 이에 대한 연구개발이 활성화될 것을 예상된다.

\section{후기}

본 기술해설은 한국과학기술정보연구원이 교육과학기 술부의 과학기술진흥기금으로 수행하는 ReSEAT 프로 그램의 성과물입니다.

\section{참 고 문 헌}

1. A. Koscielna, W. Szkliniarz : Effect of cyclic heat treatment parameters on the grain refinement of Ti-48Al-2Cr-2Nb alloy, Materials Characterization 60 (2009) 1158

2. Y. W. Kim, A. Rosenberger, D. M. Dimiduk : Microstructural changes and estimated strengthening 
contributions in a gamma alloy Ti-45Al-5Nb packrolled sheet, Intermetallics 17 (2009) 1017

3. I. C. Wallis et al. : Brazed joints in $\mathrm{r}^{-T i A l}$ sheet: microstructure and properties, Intermetallics 12 (2004) 303 316

4. R. K. Shiue, S. K. Wu, S. Y. Chen : Infrared brazing of TiAl using Al-based braze alloys, Intermetallics 11 (2003) 661 671

5. Zhenwen Yang et al. : Microstructural evolution and mechanical properties of the joint of TiAl alloys and $\mathrm{C} / \mathrm{SiC}$ composites vacuum brazed with $\mathrm{Ag}-\mathrm{Cu}$ filler metal, Materials Characterization 62 (2011) 825 832

6. R. K. Shiue et al. : Infrared brazing of Ti50Al50 and Ti-6Al-4V using two Ti-based filler metals, Intermetallics, 16 (2008) 1083 1089

7. Peng $\mathrm{He}$ et al. : Effect of mechanical milling on $\mathrm{Ni}^{-} \mathrm{TiH}_{2}$ powder alloy filler metal for brazing TiAl intermetallic alloy, Materials Characterization 60 (2009) 30 35

8. J. Cao et al. : Mechanical milling of Ti-Ni-Si filler metal for brazing TiAl intermetallics, Intermetallics 19 (2011) 855 859

9. Ja-Myoung Ku et al. : Brazing of TiAl and AISI4140 steel using an $\mathrm{Ag}-\mathrm{Cu}-\mathrm{Ti}$ insert metal, Journal of the Korean Welding and Joining Society (2004) May 45 47(in Korean)

10. Hai-xin LI et al. : Microstructure and shear strength of reactive brazing joints of $\mathrm{TiAl} / \mathrm{Ni}$-based alloy, Transactions of Non-ferrous Metals Society of China, 22 (2012) 324 329

11. Z. W. Yang et al. : Interfacial structure and fracture behavior of $\mathrm{TiB}$ whisker-reinforced $\mathrm{C} / \mathrm{SiC}$ composite and TiAl joints brazed with Ti-Ni-B brazing alloy, Materials Science and Engineering A 532 (2012) 471 475

12. R. K. Shiue et al. : Infrared brazing of TiAl intermetallic using BAg-8 braxe alloy, Acta Materialia 51 (2003) 1991 2004

13. S. L. Draper et al. : Development and evaluation of TiAl sheet structures for hypersonic applications, Materials Science and Engineering A 464 (2007) 330 342

14. L. I. Duarte et al. : Solid-state diffusion bonding of gamma-TiAl alloys using $\mathrm{Ti} / \mathrm{Al}$ thin films as interlayers, Intermetallics 14 (2006) 1151 1156

15. R. K. Shiue et al. : Infrared brazing of TiAl intermetallic using BAg-8 braze alloy, Acta Materialia, 51 (2003) 1991 2004

16. H. J. Liu et al. : Interface structure and formation mechanism of diffusion-bonded joints of $\mathrm{SiC}$ ceramic to TiAl-based alloy Scripta Materialia 43 (2000) 49 53

17. Yulong Li et al. : Interface structure and mechanical properties of the TiAl/42CrMo steel joint vacuum brazed with $\mathrm{AgCu} / \mathrm{Ti} / \mathrm{Ag}-\mathrm{Cu}$ filler metal, Scripta Materialia 55 (2006) 171 174
18. J. C. Feng, J. Cao, Z. R. Li : Microstructure evolution and reaction mechanism during reactive joining of TiAl intermetallic to TiC cermet using $\mathrm{Ti}-\mathrm{Al}-\mathrm{C}-\mathrm{Ni}$ interlayer, Journal of Alloys and Compounds 436 (2007) 298 302

19. H. P. Xiong, Q. Shen, J. G. Li, L. M. Zhang, R. Z. Yuan, J. Mater. Sci. Lett. 19 (2000) 989.

20. Hua-Ping Xiong et al. : Formation of silicide coatings on the surface of a TiAl-based alloy and improvement in oxidation resistance, Materials Science and Engineering 391 (2005) 10 18

21. G. X. Luo et al. : Diffusion bonding of lasersurface-modied gamma titanium aluminide alloy to nickel-base casting alloy, Script Materialia, 57 (2007) 521 524

22. T. Tetsui et al : Gamma Ti aluminides for nonaerospace applications, Current Opinion Solid state \& Materials Science, 4 (1999) 243 248

23. FAN Kun et al. : Present research status of brazing technology of TiAl-based alloy, Welding Technology, 33(1) (2004) 35

24. P. He et al. : Effect of mechanical milling on $\mathrm{Ni}-\mathrm{TiH} 2$ powder alloy filler metal for brazing TiAl intermetallic alloy, Materials Characterization, 60 (2009) 3035

25. Duan Hui-ping et al. : Transient liquid phase bonding of TiAl and Inconel 718, Journal of Beijing University of Aeronautics and Astronautics, 30(10) (2004) 984 988. (in Chinese)

26. L. I. Hai-xin et al. : Microstructure and shear strength of reactive brazing joints of $\mathrm{TiAl} / \mathrm{Ni}$-based alloy, Trans. Non-ferrous Met. Soc. China 22 (2012) 324 329

27. Houqin Wang et al. : Brazing mechanism and infiltration strengthening of CC composites to TiAl alloys joint, Scripta Materialia 63 (2010) 859 862

28. T. Noda, Application of cast gamma TiAl for automobiles, Intermetallics 6 (1998) 709 713

29. J. Cao et al. : Effect of reaction heat on reactive joining of TiAl intermetallics using Ti-Al-C interlayers, Scripta Materialia 57 (2007) 421 424

30. R. K. Shiue, S. K. Wu, S. Y. Chen : Infrared brazing of TiAl intermetallic using $\mathrm{BAg}-8$ braze alloy, Acta Mater. 51 (2003) 1991 2004

31. H. Y. Chan, D. W. Liaw, R. K. Shiue, Int. J. Refract. Met. Hard Mater. (2004) 27 33

32. P. He, J. C. Feng, B. G. Zhang, Q. Yiyu : Mater. Charact. 50 (2003) 87 92

33. P. He, J. C. Feng, W. Xu : Interfacial microstructure of induction brazed joints of TiAl-based intermetallics to steel 35CrMo with AgCuNiLi filler, Materials Science and Engineering A 408 (2005) 195 201

34. P. He, J. C. Feng, W. Xu : Mechanical property and fracture characteristic of induction brazed joints of TiAl-based intermetallics to steel 35CrMo with $\mathrm{Ag}-\mathrm{Cu}-\mathrm{Ni}-\mathrm{Li}$ filler, Materials Science and 
Engineering A 412 (2005) 214 221

35. P. He, et al. : Mechanical property of induction brazing TiAl-based intermetallics to steel $35 \mathrm{CrMo}$ using AgCuTi filler metal, Materials Science and Engineering A 418 (2006) 45 52

36. P. He, et al. : Microstructure and kinetics of induction brazing TiAl-based intermetallics to steel $35 \mathrm{CrMo}$ using AgCuTi filler metal, Materials Science and Engineering A 418 (2006) 53 60

37. S. J. LEE et al. : Infrared joining of TiAl intermetallics suing $\mathrm{Ti}-15 \mathrm{Cu}-15 \mathrm{Ni}$ foil, Acta materialia 46(4) (1998) 1283 1295

38. A. S. Ramos et al. : Nanometric multilayers: A new approach for joining TiAl, Intermetallics 14 (2006) 1157 1162

39. Won-Bae Lee et al. : Effects of copper insert layer on the properties of friction welded joints between TiAl and AISI 4140 structural steel, Intermetallics 12 (2004) $671 \sim 678$

40. Hua-Ping Xiong et al. : Liquid-phase siliconizing by $\mathrm{Al}-\mathrm{Si}$ alloys at the surface of a TiAl-based alloy and improvement in oxidation resistance, Acta Materialia 52 (2004) 2605 2620

41. T. Noda et al. : Inductive brazing of TiAl and steels, Materials Science and Engineering A239-240 (1997) 613 618

・유호천
-1951년생
- 한국과학기술정보연구원 전문연구위원
・금속공학, 용접야금 및 공정, 정보분석
- e-mail : yooho278@ reseat.re.kr

42. X. G. Song et al : Effect of $\mathrm{Si}_{3} \mathrm{~N}_{4}$-particles addition in $\mathrm{Ag}-\mathrm{Cu}-\mathrm{Ti}$ filler alloy on $\mathrm{Si}_{3} \mathrm{~N}_{4} / \mathrm{TiAl}$ brazed joint, Materials Science and Engineering A 528 (2011) $5135 \sim 5140$

43. X. G. Song et al. : Brazing high Nb containing TiAl alloy using $\mathrm{TiNi}-\mathrm{Nb}$ eutectic braze alloy, Intermetallics 22 (2012) $136 \sim 141$

44. I. C. Wallis et al. : Brazed joints in $\mathrm{r}^{-T i A l}$ sheet: microstructure and properties, Intermetallics 12 (2004) 303 316

45. J. Cao et al. : Combustion synthesis of TiAl intermetallics and their simultaneous joining to carbon/carbon composites, Scripta Materialia 65 (2011) 261 264

46. X. G. Song et al. : Brazing TiAl intermetallics using TiNi-V eutectic brazing alloy, Materials Science and Engineering A 551 (2012) 133 139

47. T. Tetsui, S. Ono : Endurance and composition and microstructure effects on endurance of TiAl used in turbochargers, Intermetallics 7 (1999) 689 697

48. Toshimitsu Tetsui : Effects of brazing filler on properties of brazed joints between TiAl and metallic materials, Intermetallics 9 (2001) 253 260

49. Toshimitsu Tetsui : Development of a TiAl turbocharger for passenger vehicle, Materials Science and Engineering, 331 (2002) 582 588 